\title{
Trešās personas verbu saistāmība ar g̊enitīvu: „Līdzsvarotā mūsdienu latviešu valodas tekstu korpusa" dati
}

\section{Combinability of third-person verbs with genitive: data of ,The balanced corpus of Modern Latvian”}

\author{
Gunta Nešpore-Bērzkalne \\ Latvijas Universitātes \\ Matemātikas un informātikas institūts \\ Raina bulvāris 29, Rīga, LV-1050 \\ E-pasts: gunta.nespore@lumii.lv
}

Izmantojot „Līdzsvarotā mūsdienu latviešu valodas tekstu korpusa” datus, rakstā analizēti trešās personas (resp. vienpersonas) verbi gribēties, iegribēties, sagribēties, pietikt, trūkt, pietrūkt, vajadzēt, ievajadzēties, savajadzēties, kas tradicionāli saistās ar g̊enitīvu, bet mūsdienu valodā tiek lietoti arī ar citiem locìjumiem - nominatīvu un akuzatīvu. Konstatēts, ka pie verbiem pietikt, trūkt, pietrūkt joprojām dominē ǵgenitīvs, lai gan atsevišksos gadījumos sastopams arī nominatīvs, savukārt pie verbiem vajadzēt, ievajadzèties, savajadzēties, gribēties, iegribēties un sagribēties g̊enitīvs visbiežāk tiek aizstāts ar akuzatīvu.

Atslēgvārdi: trešās personas verbi; saistāmība; g̊enitīvs; akuzatīvs; nominatīvs; latviešu valodas tekstu korpuss.

\section{Ievads}

Inta Freimane $(2008$, 90) monogrāfijā „,Trešā persona latviešu verbu sistēmā” min šādus trešās personas verbus ${ }^{1}$, kas tradicionāli saistās ar ğenitīvu: gribēties, iegribēties, sagribēties, pietikt, trūkt, pietrūkt, vajadzēt, ievajadzēties. Kā raksta I. Freimane (2008, 90), „minētie verbi pieder pie pasīvās personas lauka - tie nosauc psihiskus procesus un stāvokḷus: vajadzību vai tās noliegumu, vēlēšanos, gribas izpausmi. Ģenitīvs pie šiem verbiem nosauc atbilstošo priekšmetisko subjektu”. Taču valodas praksē šie verbi ne vienmēr tiek lietoti saistījumā ar ğenitīvu, turklāt daži no tiem (piem., gribēties, vajadzēt) kopā ar ǵenitīvu tiek lietoti retāk nekā ar citu locījumu (šajā gadījumā - akuzatīvu).

Trešās personas verbi tiek lietoti tikai trešās personas formā, gramatikā tos tradicionāli dēvē par vienpersonas verbiem. 
Kā atzīst I. Freimane (2008, 92), šìm atkāpēm no literārās normas ir objektīvs pamatojums dzilajāās struktūrās.

Lai noskaidrotu minēto verbu saistāmības tendences valodas praksē, izmantoti „Līdzsvarotā mūsdienu latviešu valodas tekstu korpusa 2013” dati. Korpuss ir izstrādāts Latvijas Universitātes Matemātikas un informātikas institūta Mākslīgā intelekta laboratorijā 2013. gadā, tajā ir apmēram 4,5 miljoni vārdlietojumu. Jāṇem vērā, ka korpusā iekḷauti pārsvarā redig̣êti (publicēti) rakstu valodas teksti (periodika, daiļliteratūra, normatīvie akti u. c.), kuros atkāpju no valodas normām ir mazāk nekā sarunvalodā vai neredig̣ētos tekstos. Analizēti visi I. Freimanes minētie verbi, kam pievienots ar̄̄ verbs savajadzēties. Minētie verbi apskatīiti arī noliegumā, ja tāds tekstu korpusā ir atrodams (tekstu korpusa datos noliegumā nav verbu ievajadzêties un savajadzêties, arī apgalvojumā šie verbi sastopami reti). I. Freimanes secinājumus salīdzināt ar mūsdienu latviešu valodas tekstu korpusa datiem īpaši interesanti ir tāpēc, ka I. Freimanes pētījumi par trešās personas verbiem veikti pirms latviešu valodas tekstu korpusu izstrādes un tekstu korpusā iekḷautie teksti ir ievērojami jaunāki par vairumu no I. Freimanes izmantotajiem tekstiem.

1. tabulā redzams, cik piemēru katrai verbu grupai (vienas saknes verbi analizēti kopā, jo būtiskas atšķirības vienas saknes verbu saistījumā ar g̊enitīvu vai locījumiem, kas to aizstāj, nav konstatētas) atlasīts no tekstu korpusa, kā arī cik gadījumos no tiem attiecīgie verbi saistās ar nomenu vai pronomenu. Jāprecizē, ka šajā grupā iekḷauti tikai piemēri, kuros nomena vai pronomena locījums ir atkarīgs no verba (nevis no, piem., mēra adverba vai cita daudzuma apzīmējuma - vajag daudz naudas), kā arī nomens vai pronomens noteiktā locịjumā atrodas pie verba, nevis ir izsecināms no konteksta, tātad tabulas labās puses ailē redzams to piemēru skaits, kas izmantojami, lai noskaidrotu, cik bieži g̊enitīvu pie analizētajiem trešās personas verbiem aizstājis cits locījums. Izņēmums ir konstrukcija ar prievārdu ar pie verbiem pietikt/nepietikt (piem., ar to pietiek), kas pieskaitīta un analizēta pie piemēriem, kuros verbs ir saistījumā ar nomenu vai pronomenu.

\begin{tabular}{|c|c|c|}
\hline Verbi & 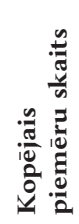 & 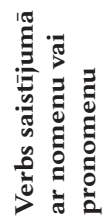 \\
\hline Trūkt, pietrūkt, netrūkt, nepietrūkt & 802 & 767 \\
\hline Pietikt, nepietikt & 558 & 403 \\
\hline Gribēties, sagribēties, iegribēties, negribēties, nesagribēties, neiegribēties & 898 & 88 \\
\hline Vajadzēt, ievajadzēties, savajadzēties, nevajadzēt & 3547 & 198 \\
\hline
\end{tabular}

1. tabula. Analizētie trešās personas verbi un to lietojuma piemēru skaits. 
Kā redzams 1. tabulā, verbi trūkt un pietikt lielākajā daḷā gadījumu saistās ar nomenu vai pronomenu, savukārt verbi gribēties un vajadzēt ar nomenu vai pronomenu saistās relatīvi reti - mazāk nekā 10\% gadījumu. Verbi gribèties un vajadzēt visbiežāk tiek lietoti kopā ar infinitīvu, un tiem ir semantisko modificētāju funkcija. Piem.:

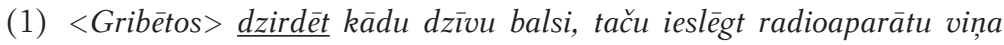
neuzdrošinās..

(2) Man vienkārši < gribējās > pamēégināt, kā tas ir - būt par avīžpuiku.

(3) Tā laikam <nevajadzēja $>\underline{\text { darìt. }}$.

(4) .. visiem <vajag $>$ stāvèt rindā un būt klusiem.

Verbs trūkt ar infinitīvu netiek lietots, bet verbam pietikt tekstu korpusā atrodami nedaudzi lietojuma piemēri arī kopā ar infinitīvu, lai gan tiek uzskatīts, ka verbi trūkt un pietikt ar infinitīvu tiešā veidā nesaistās (Freimane, 2008, 100-101):

(5) .. pēe zvanīšanas pie durvīm < pietiek $>$ atbildèt-Mareuss ..

(6) $-<$ Pietiek $>$ blēnoties!

(7) <Pietiek> ielūkoties privātskolu mājas lapās ..

Apskatītie verbi mēdz piesaistīt arī palīgteikumus (8., 9. un 10. piemērs) un adverbus ar kvantitatīvu nozīmi (11., 12. un 13. piemērs), izņemot verbu pietikt, kura apkaimei nav raksturīgi šādi adverbi, un verbu trūkt, kas parasti nepiesaista palīgteikumu (līdzīgi kā infinitīvu):

(8) $<$ Vajag >, lai ìstajā brīdì kāds pagrūžz...

(9) Optimālā variantā pat <pietiek>, ja katlu kurina reizi diennaktī.

(10) ..vinai < gribētos>, lai izrāde uzrunātu visus.

(11) <Gribētos> daudz, bet visu uzreiz finanses neḷauj ..

(12) Katru reizi lìdz uzvarai <pietrūka> pavisam nedaudz ..

(13) Tikai vinam jau vienmēr visvairāk $\langle$ vajag $>$.

Verbi vajadzēt un pietikt sastopami arī bez jebkādiem paplašinātājiem (tie vairāk vai mazāk precīzi ir izsecināmi no plašāka konteksta), piem.:

(14) Pietiekami esmu izbaudījusi tos priekus! <Pietiek>! Dēls man ir. Viss!

(15) Lauma, <pietiek>! Nerunā vairs!

(16) Argumentācija? $<$ Vajag $>$ !

(17) Vingrošana? Zinu, ka <vajadzètu>, taču esmu izturējusi četras piecas dienas.

(18) Un tad tie tusi, tie garie vakari, un tā tukšu salmu kulšana. Paldies, $<$ nevajag $>$.

Sīkāk apskatīti verbi saistījumā ar nomenu vai pronomenu. 
Visiem apskatītajiem verbiem tekstu korpusa datos parādās gan piemēri, kuros tie tiek lietoti kopā ar g̊enitīvu, gan arī piemēri, kuros g̊enitīva vietā stājies cits locījums (akuzatīvs vai nominatīvs). Tomēr atšķiras šo locījumu biežums, pie verbiem trūkt un pietikt dominē genitīvs, bet pie verbiem gribēties un vajadzēt - cits locījums.

\section{Trūkt, pietrūkt, netrūkt, nepietrūkt}

Šo verbu saistāmībā pārliecinoši dominē genenitīvs, piem.:

(19) Viñai $<$ pietrūka $>$ drosmes.

(20) Studentiem $<$ trūkst $>$ naudas.

Parādās arī nedaudzi (29 piemēri) saistījumi ar nominatīvu, bez nozīmes atškirīības no g̊enitīva, piem.:

(21) Pétījumu neesamība ir iemesls tam, ka <trūkst> latviešu valodas terminoloǵija vairāku jautājumu izklāstam.

(22) .. būt nelaimìgam tādēl, $k a<$ trūkst > citu cilvēku sabiedrība...

Izteicienu varianti, kas atšķiras tikai ar locījumu, kurā ir ar verbu saistītais pronomens, skaidri parāda, ka šie locījumi tiek lietoti bez nozīmes atškirīiām:

(23) Tas tik vēl trūka.

un

(24) Tā tik vēl trūka.

\section{Pietikt, nepietikt}

Kopā ar šiem verbiem līdzīgā biežumā sastopams g̊enitīvs un konstrukcija ar prievārdu ar, piem.:

(25) Jums vēl $<$ pietiek $>$ bezkaunības man zvanìt naktī?

(26) Ar pusi pilnīgi $<$ pietiek $>$.

Starp šīm konstrukcijām ir nozīmes atškirība. Kopā ar g̊enitīvu šie verbi izsaka nozīmi, ka iesaistîtās personas rīcībā kaut kas ir - vai nu pietiekošā daudzumā, vai, ja verbs ir noliegts, pārāk maz, bet nav runa par kādu citu objektu, kas arī būtu vajadzīgs:

(27) Vai grēku <nepietiek>, lai uzn,emtos vēl vienu?;

(28) Centības un gribēšanas vinam <pietiek>, taču masīvie slovāki itin ätri nolika jauno uzbrucēju pie vietas.

Savukārt verbs kopā ar prievārda konstrukciju izsaka arī nozīmi, ka iesaistìtās personas rīcībā kaut kas (ar nomenu vai pronomenu nosauktais) ir, bet 
ir/nav (atkarībā no tā, vai verbs ir noliegts) vajadzīgs vēl kaut kas cits. Attiecīgi - ja verbs ir noliegts (nepietikt), tiek izteikta vajadzība pēc vēl kā cita (nevis vairāk tā paša objekta, kas nosaukts ar attiecīgo nomenu vai pronomenu):

(29) Puikām ar mani <nepietiek>, - viņa uzmanīgi runāja. - Vajadzīga māte.

(30) Taču dzìvēe ar talantu vien <nepietiek>, jāiegūst arī izglìtīiba ..

Ja verbs nav noliegts, vajadzība pēc vēl kā cita nav izteikta:

(31) .. vai ar šiem resursiem un spējām <pietiek>, lai sasniegtu uznēemuma mèrkus.

(32) Ja ir lìdzīgi darba apstākḷi, <pietiek> ar apkopojošu ziṇu norādī̌šnu minētajos dokumentos.

Ja tomēr ir runa par to, ka papildus vajadzīgs tas pats, kas nosaukts ar nomenu vai pronomenu, parasti ir minēts konkrēts apjoms vai citādi konkretizēts tas, ar ko nepietiek:

(33) .. ar pieciem maziem radiatoriem <pietiek>, lai nodrošinātu mājvietā siltumu.

(34) Daugavpilij ar 6 notāriem $<$ nepietiek $>$.

Atsevišķos gadījumos („Līdzsvarotajā mūsdienu latviešu valodas tekstu korpusā" atrodami tikai 4 piemēri) g̊enitīva vietā parādās nominatīvs, kas pēc nozīmes neatškiras no g̊enitīva:

(35) .. jo citi ienākumi < pietiek> vien „pašu vēderam”.

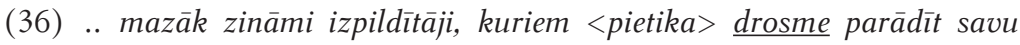
dziedātprasmi..

(37) .. ar pāris katla uzpildes reizēm siltums <pietiks> ilgākam laika posmam.

(38) Autostāvvieta .. ir liela, lai <pietiktu> vieta divām automašināàm katram dzīvoklim.

Tekstu korpusā atrodams arī viens teikums, kurā verbs nepietikt lietots kopā ar akuzatīvu, tomēr tas ir l̦ loti netipisks, iespējams, prievārds ,ar” tekstā ir izlaists kḷūàdas pēc:

(39) .. aplūrēt katru sniegpārslu - tur visu kaķa mūžu <nepietiek >.

\section{Gribēties, sagribēties, iegribēties, negribēties, nesagribēties, neiegribēties}

Ar nomeniem vai pronomeniem saistās tikai neliela daḷa no tekstu korpusā atrodamajiem verba gribèties lietojumiem (un pārējiem analizētajiem tās pašas saknes verbiem). Kā minēts iepriekš, vairumā gadījumu šie verbi saistās ar infinitīvu un funkcionē kā semantiskie modificētāji. 
Ja šie verbi ir saistījumā ar nomenu vai pronomenu, tas visbiežāk ir akuzatīvā:

(40) Bet vispirms man <gribētos> lielu virtuvi, kur to visu nolikt.

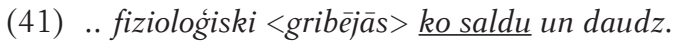

Interesanti, ka „Līdzsvarotā mūsdienu latviešu valodas tekstu korpusa dati” neatbilst I. Freimanes rakstītajam, ka akuzatīvs pie gribēties sastopams retāk (nekā pie vajadzēt) (Freimane, 2008, 92).

Pēc tekstu korpusa datiem g̊enitīvs pie šiem verbiem sastopami ārkārtīgi reti (3 piemēri):

(42) Piepeši <sagribējās $>$ kaut kā sava.

(43) Man <gribējās > miera, Augustīn!

Uz to, ka šādas konstrukcijas saistās ar novecojušu valodu, daiḷliteratūru vai ir citādi stilistiski marķētas, norādīịis arī J. Rozenbergs $(1983,21)$ un A. Kalnača $(2011,68-69)$.

Viens no šiem trim piemēriem ar g̊enitīvu ir interesants ar to, ka kā vienlīdzīgi teikuma locekḷi pie verba lietoti lietvārdi akuzatīvā un ǵenitīvā (ja vien nepieņem, ka pirmais no tiem ir daudzskaița ğenitīvā, kas būtu neparasti lietvārda leksiskās nozīmes dẹl):

(44) .. ka viņam <gribas > daudzu sieviešu draudzību un mīlēšanas.

\section{Vajadzēt, ievajadzēties, savajadzēties, nevajadzēt}

Arī šie verbi vairumā gadījumu saistās ar infinitīvu un funkcionē kā semantiskie modificētāji.

Ar nomeniem vai pronomeniem saistās tikai neliela dạ̣a no tekstu korpusā atrodamajiem šo verbu lietojuma piemēriem. Parasti šie nomeni vai pronomeni ir akuzatīvā. Piem.:

(45) Man <vajag $>$ kalnus.

(46) Iespējams, tev nemaz aptiecinu $<$ nevajadzēs $>$..

Krietni retāk (32 piemēri) šie verbi ir lietoti kopā ar ğenitīvu. Piem.:

(47) Iljam <nevajadzēja > palīga, es zināju, ka viṇš pats tiks galā.

(48) Kam tad naudas $<$ savajadzēejies $>$ ?

(49) Man <vajadzētu $>$ cukura..

Arī šo verbu lietojuma piemēros būtiskas nozīmes atšķirības starp g̊enitīvu un akuzatīvu nav manāmas. Atrodami līdzīgi teikumi, kas atšķiras ar pronomena locījumu:

(50) Nekā no tevis $<$ nevajag $>$. 
un

(51) Man neko no jums <nevajag>.

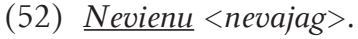

un

(53) Man vairs neviena $<$ nevajag $>$ !

Uz tendenci pie daudziem verbiem ğenitīva vietā lietot arī akuzatīvu norādījis jau J. Endzelīns un K. Mīlenbahs „Latviešu valodas mācībā” un „Latviešu gramatikā” (1907, 171-172, 1993, 205) (verbi vajadzēt un trūkt gan šeit minēti pie tiem, kas lietojami ar ğenitīvu).

Arī Dz. Paegle „Latviešu literārās valodas morfolog̣ijā” (2003, 41) min, ka mūsdienu runātāji ğenitīva konstrukcijas šādos gadījumos aizstāj ar akuzatīva konstrukcijām. „Latviešu valodas gramatikā” minēts, ka „g̊enitīva un akuzatīva sinonīmiskais lietojums veidojies laika gaitā, nivelējoties abu locījumu nozīmēm, kas bijušas atšksirīgas. [..] Mūsdienu valodas lietotāji šīs nozīmju nianses lielākoties vairs nešksir, ikdienas saziņā šādā nozīmē parasts ir akuzatīvs" (Smiltniece 2013, 348). Tekstu korpusa dati pilnībā atbilst šiem apgalvojumiem.

2. tabulā redzams, kādos locījumos un cik reižu analizētajos piemēros lietots nomens vai pronomens pie attiecīgajiem verbiem (tabulā nav iekḷauts verbs pietikt pie konstrukcijas ar priedēkli ar, tāpēc šeit minēto piemēru kopējais skaits ir mazāks nekā 1. tabulas labajā ailē minētais).

\begin{tabular}{|c|c|c|c|}
\hline Verbi & : & 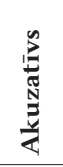 & 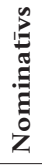 \\
\hline Trūkt, pietrūkt, netrūkt, nepietrūkt & 738 & & 29 \\
\hline Pietikt, nepietikt & 181 & 1 & 4 \\
\hline Gribēties, sagribēties, iegribēties, negribēties, nesagribēties, neiegribēties & 3 & 85 & \\
\hline Vajadzèt, ievajadzēties, savajadzēties, nevajadzēt & 32 & 166 & \\
\hline
\end{tabular}

2. tabula. Pie verbiem dažādos locījumos lietoto nomenu vai pronomenu skaits.

Kā redzams 2. tabulā, pie verbiem gribēties un vajadzēt g̊enitīvu gandrīz pilnībā ir aizstājis akuzatīvs. Tas apstiprina uzskatu, ka nomenam vai pronomenam, kas tradicionāli bijis ğenitīvā, ir objekta nozīme; tā kā valodas praksē objekta nozīmes locījums parasti ir akuzatīvs, nevis g̊́enitīvs, mūsdienu latviešu valodā akuzatīvs pie verba objekta nozīmē tiecas dominēt visos iespējamos gadījumos (Freimane 2008, 92). 
Savukārt verbi trūkt un pietikt vairumā gadījumu lietoti ar g̊enitīvu, nominatīvs tā vietā ir lietots pietiekami reti, lai to vēl aizvien varētu uzskatīt par atkāpi no normas. Tomēr fakts, ka genitīvu tiecas aizstāt nominatīvs kā subjektam raksturīgs locījums, nevis akuzatīvs kā pārējiem diviem verbiem, apliecina, ka pie verbiem trūkt un pietikt g̊enitīvam ir subjekta, nevis objekta nozìme.

\section{Secinājumi}

Apskatītās verbu grupas „Līizsvarotajā mūsdienu latviešu valodas tekstu korpusā” ir plaši pārstāvētas, tāpēc ḷauj izdarīt secinājumus par šo verbu lietošanas tendencēm mūsdienu rakstu valodā.

Pēc locịjumiem, ar ko kopā tiek lietoti verbi, tie iedalāmi divās grupās: saistījumā ar verbiem pietikt un trūkt joprojām dominē ǵenitīvs, savukārt pie verbiem vajadzēt un gribēties gandrīz vienmēr tiek lietots akuzatīvs, to vairs nevar uzskatīt par atkāpi no normas, mūsdienu tekstos tieši g̊enitīvs šķiet neierastāks.

Tādās pašās grupās verbi iedalāmi pēc tā, kurš locịjums var ieņemt g̊enitīva vietu. Pie verbiem pietikt un trūkt g̊enitīvu var aizstāt nominatīvs, bet pie verbiem vajadzēt un gribêties - akuzatīvs. Tas apstiprina uzskatu, ka genitīvam pie pirmajiem diviem verbiem ir subjekta nozīme, bet pie otrajiem diviem objekta nozīme.

\section{Avots}

Lìdzsvarots mūsdienu latviešu valodas tekstu korpuss. Pieejams: http:///www.korpuss.lv.

\section{Literatūra}

1. Endzelīns, Jānis, Mīlenbahs, Kārlis. 1907. Latviešu gramatika. Rīga: Zihmaņa apgāds.

2. Endzelīns, Jānis, Mīlenbahs, Kārlis. 1993. Latviešu valodas mācība. 14. izdevums. Rīga: Zvaigzne. [Pirmizdevums: Rīga, 1907.]

3. Freimane, Inta. 2008. Trešā persona latviešu verbu sistēmā. Rīga: LU Akadēmiskais apgāds.

4. Kalnača, Andra. 2011. Morfologiijas stilistika. Rīga: LU Akadēmiskais apgāds.

5. Paegle, Dzintra. 2003. Latviešu literārās valodas morfoloǵija. I. Rīga: Zinātne.

6. Rozenbergs, Jānis. 1983. Latviešu valodas praktiskā stilistika. II. Rīga: Zvaigzne.

7. Smiltniece, Gunta. Lietvārds (substantīvs). 2013. Latviešu valodas gramatika. Nìtiņa, Daina, Grigorjevs, Juris (red.). Rīga: LU Latviešu valodas institūts, $324-369$. 


\section{Summary}

The article deals with the third-person verbs in Latvian (gribèties 'to want', iegribêties 'to have a craving', sagribêties 'to have a craving', pietikt 'to be enough', trūkt 'to lack', pietrūkt 'to lack', vajadzēt 'to need', ievajadzēties 'to need', savajadzêties 'to need'), that traditionally are used with the genitive case, but in Modern Latvian - with other cases as well, namely - with nominative and accusative.

Data from „The balanced corpus of Modern Latvian” („Līdzsvarots mūsdienu latviešu valodas tekstu korpuss") show that verbs pietikt, trūkt, pietrūkt still mostly are combined with the genitive case, though occasionally it is substituted with nominative; whereas in connection with verbs vajadzēt, ievajadzēties, savajadzēties, gribēties, iegribèties and sagribèties the genitive case in most instances is substituted with accusative. 